\author{
Andrzej Perzanowski \\ a.perzanowski@uw.edu.pl \\ Instytut Etnologii i Antropologii Kulturowej \\ Uniwersytet Warszawski
}

\title{
ŚRODOWISKO. WYKLUCZENIE I REINTEGRACJA SPOŁECZNA W PRAKTYCE PSYCHIATRII ŚRODOWISKOWEJ
}

\author{
Community: Exclusion and Social Reintegration \\ in the Practice of Community Treatment in Psychiatry
}

\begin{abstract}
Streszczenie: Artykuł jest próbą analizy problemu wykluczenia społecznego i dyskryminacji osób z ciężkimi chorobami psychicznymi jako części doświadczenia pracowników psychiatrii środowiskowej w Polsce. Artykuł oparty jest na wynikach badań terenowych, prowadzonych w latach 2012-2014 w jednym z psychiatrycznych Zespołów Leczenia Środowiskowego w Białymstoku. Koncentruję się na codziennej praktyce, kontekstualnie kształtowanych działaniach i perspektywie etycznej terapeutek zespołu, konfrontowanych z doświadczeniem choroby, hospitalizacji i antycypowanej chroniczności pacjentów psychiatrycznych. Kluczowym aspektem analizowanego problemu jest chroniczność jako determinowana przez uwarunkowania medyczne, indywidualne i społeczne. Chroniczność obejmuje konsekwencje zaburzeń i chorób, stygmatyzacji związanej z hospitalizacją psychiatryczną, mechanizmów dyskryminacji, wykluczenia społecznego i samonaznaczenia. Odwołuję się do koncepcji etnografii daremności autorstwa Paula Brodwina, zgodnie z którą doświadczenie pracowników psychiatrii jest determinowane przez zinternalizowaną niemożność skutecznej poprawy stanu zdrowia pacjentów, konsekwencje terapeutycznych ograniczeń psychiatrii oraz bezterminowe powiązanie pacjentów i ich rodzin $\mathrm{z}$ instytucjonalną psychiatrią. Rozpatrywane łącznie doświadczenie daremności i problem chroniczności pozwalają na zbadanie sprzeczności między codzienną pracą zespołu i legitymizującym dyskursem psychiatrii: między doświadczeniem moralnym, praktyką opieki i realnymi możliwościami terapii i skutecznego zmniejszenia wykluczenia społecznego i dyskryminacji.
\end{abstract}

Słowa kluczowe: antropologia psychiatrii; psychiatria środowiskowa; chroniczność; wykluczenie społeczne; dyskryminacja; reintegracja społeczna; etnografia daremności.

Abstract: This paper is an attempt to analyze the problem of social exclusion and discrimination of persons with severe mental illnesses as a part of the experience of community psychiatry practitioners in Poland. It draws on ethnographic material collected during field research conducted from 2012 to 2014 in one of the psychiatric teams of community treatment in Bialystok. I focus on everyday practice, contextually shaped activities and the ethical perspective of the team's therapists, confronted with the experience of illness, hospitalization and anticipated chronicity of psy- 
chiatric patients. The key aspect of the analyzed problem is chronicity as determined by medical, individual and social conditions. Chronicity includes consequences of mental illnesses and disorders, stigma associated with psychiatric hospitalization, mechanisms of discrimination, social exclusion and self-stigmatization. I refer to Paul Brodwin's concept of the ethnography of futility, according to which the experience of psychiatry practitioners is determined by the internalized sense of inability to effectively improve patients' health, the consequences of therapeutic limitations of psychiatry and the indefinite attachment of patients and their families to institutional psychiatry. Considered together, the experience of futility and the problem of chronicity allows us to explore the contradictions between practitioners' everyday routines and the legitimizing discourse of psychiatry: between moral experience, care practice and real possibilities of therapy and effective reduction of social exclusion and discrimination.

Keywords: anthropology of psychiatry; community psychiatry; chronicity; social exclusion; discrimination; social reintegration; ethnography of futility.

Refleksja nad mechanizmami wykluczenia społecznego i dyskryminacji osób z chorobami psychicznymi jest silnie ugruntowana w dyskursie psychiatrii, od dawna stanowiąc część namysłu nie tylko nad kulturowym, etycznym i instytucjonalnym, ale też ściśle terapeutycznym wymiarem jej działania. Dominująca we współczesnej polskiej psychiatrii, legitymizowana teoretycznie, organizacyjnie i prawnie perspektywa, za główne narzędzie zmniejszania stygmatyzacji i zapobiegania wykluczeniu społecznemu uznaje procesy deinstytucjonalizacji i model psychiatrii środowiskowej.

Rozważania zawarte w tym artykule oparte są na badaniach etnograficznych, prowadzonych przeze mnie w latach 2012-2014 w jednym z psychiatrycznych Zespołów Leczenia Środowiskowego (ZLŚ) w Białymstoku. Skupiałem się w nich na codziennej praktyce i doświadczeniach pracowniczek zespołu: definiowaniu sytuacji osób włączonych w program ZLŚ, przyjmowanej perspektywie wobec poznawanej biografii i antycy powanej przyszłości pacjentów w kontekście ich choroby, hospitalizacji i (zakładanej) chroniczności. Zajmowało mnie postrzeganie przez nie skuteczności psychiatrii środowiskowej, rozumianej jako projekt reintegracji społecznej osób z chorobami i zaburzeniami psychicznymi oraz ograniczania stygmatyzacji i dyskryminacji. Czy i w jakim stopniu działanie Zespołu jest w ich ocenie praktyką ograniczającą wykluczenie, a na ile, jak mówi silnie ugruntowana krytyka, legitymizujący ją dyskurs pozostaje ideologią, instytucjonalną fikcją, skrywającą nieusuwalne konsekwencje chorób oraz mechanizmy wytwarzania chroniczności, pozostawiając przy tym niezmienione społeczne źródła stygmatyzacji i dyskryminacji. Na ile adekwatna jest konstatacja, że instytucjonalna psychiatria, sama 
będąc jednym ze źródeł stygmatyzacji, w niewielkim stopniu rozpoznaje społeczne uwarunkowania wykluczenia, nie dysponując zarazem skutecznymi narzędziami ich zmiany. Jak mają się kontekstualnie i indywidualnie kształtowane działania, perspektywa etyczna i rozumienie praktyczek do postulatów społecznej reintegracji osób chorych, zawartych w programie psychiatrii środowiskowej. W jakim stopniu wpływają one na mechanizmy, za pośrednictwem których skutki chorób i praktyki dyskryminacji, „wytwarzały jednostki, których tożsamość jako osób była drugorzędna wobec tożsamości jako pacjentów psychiatrycznych" (Barham 1997: 99).

Ponieważ opisywany przeze mnie zespół zajmuje się głównie osobami ze schizofrenią, często z historią wielokrotnej hospitalizacji, najistotniejszym wymiarem badanej problematyki jest chroniczność, którą rozumiem jako złożony konstrukt, obejmujący konsekwencje zaburzenia i choroby, stygmatyzacji związanej z hospitalizacją psychiatryczną, mechanizmów dyskryminacji, wykluczenia społecznego i samonaznaczenia (Van Dongen 1998: 189, Peter 2010: 22). Chroniczność jest wytwarzana przez choroby i izolacyjne praktyki instytucjonalnej psychiatrii, jednak jako diagnoza i etykieta przede wszystkim definiuje bieżącą sytuację i determinuje przyszłość pacjentów.

Kluczowe znaczenie ma tu problematyzacja chroniczności, oddzielająca perspektywę osoby (doświadczanie objawów łączonych z chorobą) i funkcjonalną niepełnosprawność. Choroba i niepełnosprawność nie są ani synonimiczne, ani nawet bliskie sobie (Bachrach 1988: 383). Samą kategorię chroniczności należy rozpatrywać jako nacechowaną etycznie i jako narzędzie władzy: odwołanie do niej wiąże się z diagnozą psychiatryczną, sama potencjalność, która może mieć charakter destruktywny i kontrolujący (Bracken, Thomas 2005), oznacza też formułowanie prognoz, przesądzających o nieodwracalności choroby i nieskuteczności terapii - a de facto także o wykluczeniu społecznym. Posługiwanie się kategorią chroniczności w praktyce psychiatrii jest rozpatrywane jako forma stygmatyzacji i wykluczenia, lecz znaczące są tu niepowodzenia poszukiwań niestygmatyzujących określeń, jak „przewlekłe”, „poważne” itp. w miejsce „chroniczne”. Wynikały one z błędnego zdefiniowania społecznych uwarunkowań wykluczenia: „Wszelkie zabiegi językowe po pewnym czasie okazują się nieskuteczne, skoro każde określenie sugerujące długą hospitalizację lub styczność z instytucjami psychiatrycznymi jest społecznie stygmatyzowane" (Bachrach 1988: 387). Założenie chroniczności i jego konsekwencje, rozumiane jako rozpoznanie i antycypacja, traktuję jako element organizujący praktykę pracowniczek ZLŚ. 
Koncepcje antropologiczne, do których odwołuję się w artykule, łączy perspektywa, którą można określić jako anty-antypsychiatryczną ${ }^{1}$ etnograficzne badanie instytucjonalnych praktyk psychiatrii uwzględnia zarówno realność choroby (życzliwość i „siła dobrych intencji” krytyków psychiatrii nie usuną konsekwencji chorób psychicznych [Barham, Hayward 2002: 5]), jak i znaczenie uwarunkowań społecznych w wytwarzaniu chroniczności. Nawiązują one do tez wczesnych badań nad społeczno-kulturowymi uwarunkowaniami wykluczenia osób z chorobami psychicznymi w kontekście deinstytucjonalizacji i psychiatrii środowiskowej (Scheper-Hughes 1982, Estroff 1985), uwzględniają trwałość mechanizmów wykluczenia, którą potwierdzają współczesne badania (Link, Phelan 2010, Kiejna i in. 2014), a jednocześnie odrzucają argumentację konstytuującą radykalną krytykę praktyk psychiatrii (Paulson 2012).

Swoje badania amerykańskiej psychiatrii środowiskowej Paul Brodwin (2011, 2013) określa mianem etnografii daremności: doświadczenie pracowników jest definiowane przez rozpoznanie bezsilności, rozumianej jako niemożność skutecznej poprawy stanu zdrowia pacjentów i brak szans trwałego wyleczenia. Wnioski Brodwina ukazują w pisane w praktykę psychiatrii środowiskowej sprzeczności i napięcia między wymogami systemu a wartościami, dążeniami i realnymi możliwościami zaangażowanych osób. Nieskuteczność terapeutyczna (wobec medycznego imperatywu działania na rzecz stałej poprawy stanu pacjentów) staje się obciążającym wyzwaniem (Brodwin 2011: 192)2. Daremność jest jednak definiowana nie tyle jako poddanie się obiektywnym, medycznym uwarunkowaniom, co część etosu pracy, ukazując społeczno-kulturowe, kontekstualne uwikłanie podejmowania decyzji i działań w ramach opieki zdrowotnej. Sytuując się w części praktyki psychiatrii opisywanej przez Brodwina w kategoriach impasu i sprzeczności, nie oznacza ona postawy defetyzmu i zakwestionowania sensu pomocy. Własne działania i sytuacja pacjentów rozpatrywane są z jednej strony, w kontekście znanych pracownikom wcześniejszych metod terapii i opresyjnych praktyk instytucjonalnych, z drugiej zaś, w odniesieniu do destruktywnej alternatywy, jaką byłaby rezygnacja z dostępnych form leczenia (Brodwin 2013: 70). Daremność jest „realistycznym” rozpoznaniem kontekstu działania. W pracy psychiatrów paradoksalnie to dominujący sposób

\footnotetext{
${ }^{1}$ Mam na myśli np. krytykę perspektywy radykalnego upodmiotowienia autorstwa Paula Brodwina (2013).

${ }^{2}$ Badani przez Lornę Rhodes psychiatrzy określali ten aspekt swojej pracy jako obciążenie „niemożliwym zobowiązaniem" (1991: 1).
} 
definiowania ciężkich chorób (np. schizofrenii) jako chronicznych i neurodegeneracyjnych sprawia dodatkowo, że każde leczenie, ograniczające możliwość nawrotu, staje się wartością (Brodwin 2011: 204-205).

Tak zdefiniowany problem dopełniają wnioski z badań Annemarie Mol, mówiące, że nawet jeśli „interwencje w życie i ciała osób z chronicznymi chorobami są oparte na [profesjonalnej] wiedzy", stanowią formę opieki (Mol 2008: 1). Dotyczy to sytuacji, kiedy leczenie nie prowadzi do wyzdrowienia, lecz ma na celu szeroko rozumianą poprawę dobrostanu. Podobnie jak Brodwin, Mol wskazuje, że tego rodzaju opieka nie opiera się na celach ściśle medycznych i argumentacyjnej bioetyce, będąc jednocześnie działaniem istotnym i moralnym (jej badanie Brodwin nazywa „etnografią codziennej etyki” [2013: 13]). Analityczne rozróżnienie terapii i opieki rzuca światło na ważną część praktyki ZLŚ.

Cheryl Mattingly, badająca doświadczenia rodzin osób chronicznie chorych, odwołuje się do kategorii „chronicznej pracy domowej” (2014: 71), opisującej poszukiwanie „życia wartego życia nawet wśród cierpienia, nawet bez dostrzeganego szczęśliwego wyjścia" (Mattingly 2010: 6). Etnograficzną perspektywę w badaniu chroniczności definiuje jako ukazywanie praktyki będącej przestrzenią możliwości, a nie jedynie determinizmu lub strukturalnej reprodukcji (Mattingly 2010: 39). Wprowadza także kluczowe pojęcie „podzielanej chroniczności”, wiążącej pacjentów i ich rodziny oraz opiekę medyczną (Mattingly 2010:4).

Wymiar podzielanej chroniczności włącza wzajemne zobowiązania i oczekiwania pacjentów, rodzin i instytucji, co także określa działania pracowniczek ZLŚ. Etnograficzne badanie ukazuje je jako kształtowane przez uznanie ograniczonych możliwości terapii, praktykę opieki, trwały status pacjenta i (podzielaną) chroniczność.

\section{Psychiatria środowiskowa: terapia, etyka i reintegracja społeczna}

Psychiatrię w Polsce w jej wymiarze teoretycznym jednoczy zgoda co do pożądanego kierunku zmian instytucjonalnych, które można sprowadzić do rozwoju opieki środowiskowej w powiązaniu z procesami deinstytucjonalizacji. Ich głównym założeniem jest ograniczenie roli dużych szpitali psychiatrycznych - jako przestrzeni alienacji, praktyk dyscyplinujących i stosowania przymusu, uznanych za źródło i symbol społecznej stygmatyzacji i dyskryminacji osób z zaburzeniami psychicznymi - na rzecz niedetencyjnych form opieki i terapii prowadzonych jak 
najbliżej społecznego środowiska pacjentów. Z jednej strony, chodzi o uniknięcie uprzedmiotowienia, wyuczonej bierności, „cywilnej śmierci” i „choroby instytucjonalnej" jako skutków hospitalizacji, z drugiej zaś, o usunięcie stygmatyzacji, jaka towarzyszy każdemu kontaktowi czy skojarzeniu z instytucjonalną psychiatrią.

Psychiatria środowiskowa została pomyślana jako połączenie "przesłania moralnego (idea przyjaznej wspólnoty), systemu organizacyjnego (środowiskowy model psychiatrycznej opieki zdrowotnej) i metody leczenia i rehabilitacji” (Wciórka 2000: 19), ale też jako koncepcja scalająca zadania dyscypliny naukowej, przedmiotu edukacji i działania praktycznego: ma być „psychiatrią społeczności lokalnej” (Załuska i in. 2007: 11). Ten ugruntowany dyskurs wydaje się potwierdzać analiza współczesnych psychiatrycznych konceptualizacji teoretycznych, empirycznych (prowadzonych przez samych psychiatrów) badań dotyczących praktycznej realizacji programów terapeutycznych, podręczników psychiatrii oraz obowiązującego i planowanego ustawodawstwa.

Podręczniki zalecają terapię bez odrywania pacjenta od „naturalnego miejsca życia, środowiska, w którym funkcjonuje”, z wykorzystaniem „potencjału terapeutycznego tego środowiska" (Pietrzykowska 2011: 605). Chodzi nie tylko o zapobieganie takim skutkom hospitalizacji jak „zespół instytucjonalizmu” i chroniczność, od dawna rozpoznaną jako wytwarzaną po części przez instytucję totalną, formę „choroby instytucjonalnej” czy „choroby szpitalnej” (Różycki 1971: 365)³. Równie ważne jest uniknięcie związanej z tym stygmatyzacji społecznej.

Teoretyczne rozpoznanie mówi, że: „W trakcie trwania choroby wiele osób chronicznie chorych psychicznie doświadcza zmniejszenia się ich sieci społecznych, co prowadzi do ograniczonej zdolności radzenia sobie z trudnymi sytuacjami. Jest to szczególnie ważne w odniesieniu do osób żyjących w społecznościach lokalnych" (Bronowski i in. 2011: 32, zob. też: Bronowski, Załuska 2008). Leczenie środowiskowe ma się skupiać na ograniczeniu liczby i długości hospitalizacji, lecz przede wszystkim na utrzymaniu osób chorych w ich społecznościach; warunkiem tego ostatniego jest „ilość i jakość indywidualnych sieci społecznych osoby chorej psychicznie" oraz obecność bliskich przyjaciół i osób, na których można polegać w sytuacjach trudnych lub kryzysowych (Bronowski i in. 2011: 31).

\footnotetext{
${ }^{3}$ Ten sam autor pisał o „chorobie szpitalnej”: „podobny zespół objawów widoczny jest u ludzi przebywających w innych instytucjach niż szpitale psychiatryczne - jak w obozach jeńców wojennych, obozach uchodźców, sierocińcach, sanatoriach przeciwgruźliczych, więzieniach czy konwentach" (Różycki 1971: 364).
} 
Badania psychiatryczne sytuacji osób z ciężkimi chorobami psychicznymi dowodzą z kolei, że „przebywanie w różnorodnych instytucjach psychiatrycznych" prowadzi często do „marginalizacji społecznej tej grupy chorych. Próbą przeciwdziałania procesowi powolnej degradacji społecznej są środowiskowe programy wsparcia społecznego skierowane do osób chorych psychicznie. [...] Służą one z jednej strony budowaniu nowych, a z drugiej, odtwarzaniu zanikających umiejętności społecznych, pozwalających na skuteczne funkcjonowanie w środowisku" (Bronowski in. 2009: 43).

Ustawodawstwo psychiatryczne także stawia sobie obecnie za cel rozwijanie opieki środowiskowej, rozumianej jako część procesów deinstytucjonalizacji. Zgodnie z rozpoznaniem zawartym w Narodowym Programie Ochrony Zdrowia Psychicznego, w Polsce „dominuje archaiczny model totalnej opieki insty tucjonalnej zamiast usług wspierających świadczonych w środowisku zamieszkania”. Odwołując się do oceny Rzecznika Praw Obywatelskich, stwierdzono o pacjentach psychiatrycznych, że „w celu realizacji ich praw niezbędne jest między innymi zintensyfikowanie działań dotyczących odejścia od opieki instytucjonalnej na rzecz opieki świadczonej na poziomie lokalnych społeczności (tzw. deinstytucjonalizacja)". Skutkiem tego ma być „zmiana aksjologiczno-kulturowa” związana z postawami społecznymi wobec osób z zaburzeniami psychicznymi: „przeciwdziałanie ignorancji, procesom napiętnowania, nierównego traktowania i wykluczenia"”.

Nie rozwijając w tym miejscu wątku przekładania się teoretycznych i prawnych postulatów na praktykę i całokształt opieki psychiatrycznej w Polsce można jedynie powiedzieć, że Narodowy Program Ochrony Zdrowia Psychicznego na lata 2011-2015 nie został zrealizowany, a jego projekt na lata 2016-2020 nie został do wiosny $2017 \mathrm{r}$. przyjęty przez rząd i wymaga aktualizacji ${ }^{5}$. Poza zakres problemowy tego artykułu wykracza inny, ważny aspekt, jakim jest bardzo ograniczona w polskim dyskursie psychiatrycznym recepcja rozbudowanej krytyki procesów deinstytucjonalizacji, głównych założeń psychiatrii środowiskowej i ich stricte postulatywnego charakteru w Stanach Zjednoczonych i w wielu krajach Europy Zachodniej.

Psychiatria środowiskowa od swego początku była obszarem bliskiego zainteresowania antropologii, przede wszystkim przez jej wpisanie w historię kry-

\footnotetext{
${ }^{4}$ Narodowy Program Ochrony Zdrowia Psychicznego na lata 2016-2020, projekt rozporządzenia Rady Ministrów z dnia 05.01.2016, s. 19, 33-34.

${ }^{5}$ Raport NIK Realizacja zadań Narodowego Programu Ochrony Zdrowia Psychicznego, 25.01.2017 r. NIK postuluje jak najszybsze przygotowanie programu na lata 2017-2020. Zob.: https://www.nik.gov.pl/ plik/id,12692,vp,15090.pdf. Dostęp: 15.03.2017 r. Kluczowym elementem każdego z programów jest wdrażanie psychiatrii środowiskowej.
} 
tyki opresyjnych praktyk psychiatrii i społeczno-kulturowy kontekst procesów deinstytucjonalizacji. Dotyczy to zresztą - co wynika z wyjątkowego statusu psychiatrii jako przedmiotu akademickich badań i krytyki społecznej - wszystkich jej koncepcji teoretycznych, praktyk terapeutycznych i rozwiązań instytucjonalnych; inne dziedziny medycyny nie mają odpowiedników „anty psychiatrii”, trudno szukać propozycji w rodzaju „antypediatrii”, „anestezjologii krytycznej” etc. (Bracken, Thomas 2001: 724). Także współczesne antropologiczne badania analizujące dyskurs psychiatryczny są po części zapisem krytyki opieki środowiskowej w duchu antypsychiatrii, formułującej oskarżenia o ideologizację (Drake i in. 2003: 428), pseudonaukowość, biologiczny redukcjonizm, medykalizację, uprzywilejowanie interesów korporacji farmaceutycznych kosztem potrzeb cierpiących osób (Brodwin 2013: 183). Od początku dostrzegano również zasadnicze sprzeczności i ograniczenia wpisane w główne założenia i cele psychiatrii środowiskowej: skoncentrowanie na uwolnieniu z izolacji szpitalnej sprzyjało pomijaniu rozpoznania otoczenia społecznego osób chorych („środowiska”) jako przestrzeni wykluczenia, konfliktów i sprzeczności (Barham 1993: 181).

Antropologia psychiatrii i doświadczenia samych pracowników opieki psychiatrycznej w wielu społeczeństwach zachodnich pokazują, że nie tylko stygmatyzacja i wykluczenie wciąż pozostają podzielanym doświadczeniem osób z chronicznymi chorobami i hospitalizowanych, ale że zaskakująco trwałe są ich uwarunkowania i źródła. Współczesne opracowania polskie (zob. np.: Brodniak 2000a, 2000b; Kiejna i in. 2014) współbrzmią z poniższymi wnioskami:

badania pokazują, że mimo dużego postępu w rozpoznaniu chorób psychicznych [...] najważniejsze stereotypy dotyczące zagrożenia i niekompetencji zmieniły się niewiele bądź nawet uległy wzmocnieniu. Zyskującej na znaczeniu medycznej koncepcji choroby psychicznej nie towarzyszą żadne zmiany związane ze społecznym dystansem (Link, Phelan 2010: 587).

Kontekstem moich badań jest tym samym znaczenie nadawane modelowi środowiskowemu w dyskursie psychiatrii i rozwiązaniach instytucjonalnych w Polsce, w połączeniu z trwałymi uwarunkowaniami wykluczenia osób diagnozowanych jako chronicznie chore psychicznie. 


\section{Mit deinstytucjonalizacji}

Przykładem modnej obecnie mądrości jest naiwne przekonanie, że jeśli instytucje psychiatryczne przyczyniają się do chroniczności chorób psychicznych na Zachodzie, to rozwiążemy problem chroniczności oraz oszczędzimy pieniądze podatników, zamykając tak wiele szpitali stanowych, tak szybko i humanitarnie jak to możliwe, przywracająctym samym zdeinstytucjonalizowanych pacjentów terapeutycznym dobrodziejstwom życia we wspólnocie (Scheper-Hughes 1982: 2).

Nancy Scheper-Hughes w swojej dekonstrukcji „mitu deinstytucjonalizacji” (Scheper-Hughes 1982: 6) wskazuje na źródła jej niepowodzenia, wynikające z błędnego rozpoznania społeczno-kulturowych uwarunkowań i mechanizmów wykluczenia osób z chorobami psychicznymi. Podstawą delegitymizującej krytyki deinstytucjonalizacji było w równym stopniu odczytanie jej jako koncepcji społeczno-ekonomicznej i elementu polityki społecznej: jako jednej z inicjatyw lat 60. XX wieku, którym towarzyszyły wielkie oczekiwania, a które skutkowały neokonserwatywnymi rozwiązaniami skierowanymi przeciwko państwowemu zaangażowaniu w opiekę zdrowotną (Mechanic, Rochefort 1990: 322). Szybkiemu tempu deinstytucjonalizacji towarzyszył początkowo wielki entuzjazm obejmujący zarówno psychiatrów, jak i urzędników oraz dużą część społeczeństw; zmiany traktowano jako psychiatryczną rewolucję, przejaw postępu nie tylko medycznego, ale i humanitarnego, mającego „Wymieść mroczną epokę instytucjonalnego zamknięcia” (Mechanic, Rochefort 1990: 302). Z perspektywy lat konstatowano, że tylko tego rodzaju ideologiczny konsensus mógł dać niezbędną energię do przebudowania systemu opieki opartego na dużych szpitalach psychiatrycznych. Jedynie pozornym paradoksem jest przy tym fakt, że postulat zamykania wielkich szpitali psychiatrycznych wysuwało tak wiele środowisk społecznych: od radykalnie postępowych po konserwatywne. Łączyły je powszechne w społeczeństwach zachodnich nieufność i strach przed instytucjami totalnymi, sprzecznymi z post-oświeceniowym etosem indywidualistycznym i konwencjonalną bioetyką, która także kładła nacisk na takie wartości, jak autonomia jednostki, indywidualizm, samostanowienie, zdolność i wymóg dokonywania wyboru itp. (Brodwin 2008: 128). Jak zauważa Scheper-Hughes, swój duży wkład miała także antropologia, racjonalizując idee deinstytucjonalizacji (Scheper-Hughes 1982: 9).

Od lat 80. XX wieku można mówić o radykalnej krytyce, traktującej deinstytucjonalizację jako klęskę polityki związanej przede wszystkim z reintegracją społeczną 
osób z chronicznymi chorobami psychicznymi; uniwersalnym zarzutem był brak form wsparcia poza szpitalem (Kleinman 1988: 58). Zważywszy, że były to spośród pacjentów psychiatrycznych osoby najbardziej potrzebujące opieki, porzucenie chronicznie chorych uznawano za szczególnie przewrotną konsekwencję deinstytucjonalizacji (Scull 1989: 9). Nawet jeśli nie we wszystkich krajach dochodziło do sytuacji tak skrajnych, jak w Stanach Zjednoczonych, gdzie setki tysięcy osób dotknęła bezdomność, uwięzienie i narażenie na przemoc (Lamb 2001: 16), powszechne było doświadczanie alienacji społecznej, samotności, braku pracy, uzależnienia od wypłat z pomocy społecznej, nie wspominając o trwałym związaniu $\mathrm{z}$ instytucjami psychiatrycznymi (Paulson 2012: 185). Innymi słowy ograniczaniu hospitalizacji nie towarzyszyło kluczowe dla całego projektu powstawanie wystarczająco licznych, bliskich środowisku pacjentów, niedetencyjnych ośrodków terapii oraz programów reintegracji społecznej. Niemal całkowicie poza programem i polem zainteresowan deinstytucjonalizacji pozostawała kwestia rozpoznania społecznych i rodzinnych uwarunkowań stygmatyzacji i dyskryminacji osób z chronicznymi chorobami psychicznymi.

Odwołanie do historii procesów deinstytucjonalizacji jest tu o tyle istotne, że psychiatria środowiskowa stała się przedmiotem równie fundamentalnej, odwołującej się do podobnych argumentów krytyki, przyrównującej ją do nowego mitu i ideologii psychiatrii (Parry-Jones 1981: 213). Lecz to nie negatywne konsekwencje deinstytucjonalizacji były celem przypomnienia argumentacji autorstwa ScheperHughes: to raczej aktualność wskazanych w niej uwarunkowań terapeutycznych i społeczno-kulturowych, które reprodukują mechanizmy stygmatyzacji, wykluczenia i dyskryminacji osób z chronicznymi chorobami psychicznymi. Scheper-Hughes sformułowała szereg kluczowych problemów, które są stałym elementem dzisiejszych badań etnograficznych, mających za przedmiot chroniczność chorób psychicznych. Jak pisała, eksperymenty ze względną otwartością szpitali i wspólnotami terapeutycznymi, wytwarzającymi „bardziej kompetentnych społecznie i zdrowszych” pacjentów, „nie były w stanie złamać kodu chroniczności, która wiąże pacjentów ze sobą nawzajem, z personelem i samym szpitalem" (Scheper-Hughes 1982: 9). Sama zmiana organizacji terapii z zamkniętej na (bardziej) otwartą nie znosiła stygmatyzujących i destruktywnych skutków diagnozy i hospitalizacji psychiatrycznej oraz mechanizmów reprodukujących lęki i praktyki dyskryminacyjne.

Deinstytucjonalizacja i psychiatria środowiskowa często oznaczały w praktyce mylenie kwestii miejsca terapii z jej skutecznością i traktowanie środowiska jako 
z założenia korzystniejszego dla wszystkich, także ciężko i chronicznie chorych pacjentów(Lamb 2001: 15). W tym samym duchu uznawano psychiatrię środowiskową za działanie o charakterze zasadniczo „geograficznym” (Burns 2004: vii), gdzie zmiana społecznego definiowania osób z chorobami psychicznymi miała wprost wynikać z przeniesienia miejsca terapii. Przemieszczenie pacjentów ze szpitala do „środowiska” miało wywoływać skutki w sferze wartości i relacji społecznych: była to więc zmiana instytucjonalna, która swoje uzasadnienia ideologiczne czerpała ze słownika moralnego. Psychiatria środowiskowa nie usuwała również opisanego od dawna syndromu „szpitala obrotowych drzwi”, oznaczającego następujące po sobie: pobyt w szpitalu, stabilizację stanu zdrowia przy pomocy środków psychotropowych, wypisanie, naw rót choroby i kolejną hospitalizację (Brodwin 2013: 33; patrz też: Kajzer 1967: 313).

Odnosząc się do wniosków z ważnej książki Sue Estroff(1985), Nancy Scheper-Hughes wskazywała na inny, zasadniczy zarzut wobec antypsychiatrycznej argumentacji będącej podstawą deinstytucjonalizacji. Skupienie na społecznych praktykach stygmatyzacji i dyskryminacji osób z chorobami psychicznymi i wrażliwość na ich doświadczenia nie może prowadzić do prostego błędu, polegającego na negowaniu realności cierpienia lub choroby (teza o chorobie psychicznej jako konstrukcie psychiatrii) oraz odmawianiu pracownikom opieki psychiatrycznej humanitaryzmu lub dobrej woli (Scheper-Hughes 1982: 10). Krytyka ta wskazuje na ograniczenia dwóch skrajnych stanowisk, z których jedno oznacza medyczny redukcjonizm i odrzucenie społecznych uwarunkowań chroniczności chorób i przyczyn wykluczenia, drugie zaś pomijanie biologicznych uwarunkowań chorób psychicznych oraz podważanie wartości zabiegów terapeutycznych (Kleinman 1988: 75).

\section{„Środowisko"}

ZLŚ, o którym piszę, składał się w czasie moich badań z pięciu terapeutek oraz lekarza psychiatry - także kobiety - z których wszystkie miały za sobą od kilku do kilkunastu lat doświadczenia pracy w psychiatrii środowiskowej, a wcześniej także $\mathrm{w}$ zamkniętym lecznictwie psychiatrycznym ${ }^{6}$. Opieram się na piętnastu wywiadach

\footnotetext{
${ }^{6}$ Badany ZLŚ powstał na przełomie XX i XXI w. i jest jednym z dwóch istniejących w Białymstoku. Nie podaję dokładnej daty jego założenia oraz afiliacji organizacyjnej, by zapewnić większą anonimowość moich rozmówczyń.
} 
i kilku nienagrywanych rozmach, przeprowadzonych ze wszystkimi pracownicami w latach 2012-20147. Badania prowadziłem w siedzibie ZLŚ.

Wynikające z koncepcji moich badań skupienie na doświadczeniu terapeutek nie usuwa problemu braku głosu pacjentów: $\mathrm{w}$ antropologii psychiatrii, której centralnym zagadnieniem jest dyskursywne i społeczne wykluczenie perspektywy osób z chorobami psychicznymi, wybór rozmówców i pytań badawczych ma charakter tyleż metodologicznego, co etyczny. Perspektywa pacjenta w badaniu etnograficznym oznacza oddanie głosu, ale też zagrożenie błędnym rozumieniem, uprzedmiotowieniem i nadużyciem (Velpry 2008). Chodzi nie tylko o tezę, że wiedza uzyskana w warunkach nierówności spełnia funkcje dyscyplinujące (Graeber 2012:122), lecz o badanie jako formę przemocy. Badania upodmiotowiające, unikające tych zagrożeń oraz uwzględniające doświadczenie choroby, wiążą się z koniecznością dogłębnego rozpoznania uwarunkowań rozmowy, statusu głosu osoby i uwzględnienia jej stanu zdrowia ${ }^{8}$. Niedopełnienie tych warunków oznacza brak rozpoznania, na ile rozmowa jest oddaniem głosu, a na ile niezrozumieniem, ingerencją lub wykorzystaniem. W praktyce badawczej koniecznością jest dłuższa znajomość osoby, dająca rozumienie biograficzne i sytuacyjne - społeczne, rodzinne, ale też bliższe medycznemu, związane z trudnymi problemami, jak kwestia świadomej zgody i wpływ środków farmakologicznych. Uwzględniająca te wymogi etnografia z perspektywy pacjentów jest niezwykle ważna, oznaczałaby jednak odrębny projekt badawczy: przeformułowanie pytań, problemu i metody badań.

Opisy funkcjonowania ZLŚ, dotyczące zarówno założeń teoretycznych i organizacyjnych, jak i tworzenia relacji terapeutek z pacjentami i ich rodzinami pochodzą z moich badań, bez odwołania do ustanowionych formalnie zasad i regulaminów: chodziło mi przede wszystkim o kontekstualność, zlokalizowanie i przełożenie na wymiar indywidualnego doświadczenia i działania wymogów instytucjonalnych.

\footnotetext{
${ }^{7}$ Była to część szerszych badań etnograficznych, dotyczących przede wszystkim opieki rodzinnej nad osobami z chronicznymi chorobami psychicznymi, istniejącej od lat 30. XX wieku przy szpitalu psychiatrycznym w Choroszczy k. Białegostoku. Opieka rodzinna polegała na przekazywaniu do domów mieszkańców okolicznych wsi wybranych, „spokojnych” pacjentów, najczęściej (także przez brak opieki ze strony swoich bliskich) skazanych na bezterminową hospitalizację. W zamian za finansowe „opłaty za chorych" (Terajewicz 1935: 216) ze strony szpitala oraz wkład w postaci pracy w gospodarstwach, opiekunowie mieli zapewniać pacjentom „naturalne" warunki życia rodzinnego, wolne od „patologizującego" wpływu izolacji szpitalnej (zob. Borowski 1972; Falicki, Stankiewicz 1997). Konceptualnie i historycznie opieka rodzinna nie jest praktyką powiązaną z psychiatrią środowiskową.

${ }^{8}$ Niedostateczny wysiłek na rzecz głosu pacjentów niektórzy badacze przedstawiają nie tylko jako formę wykluczenia, lecz także wynik niepewności co do statusu tego głosu (Barham, Hayward 2002: 2).
} 
ZLŚ jest w potocznych rozmowach personelu nazywany „środowiskiem” (np.: „pacjent trafił do środowiska dwa lata temu” itp.), tego też określenia będę używał na potrzeby tekstu jako nazwy własnej.

Do „Środowiska” przyjmowane są osoby w różnym wieku, z historią jednej lub dwóch, ale też kilkudziesięciu hospitalizacji psychiatrycznych. Wszystkie terapeutki mówią jednak o przewadze ludzi młodszych, średnio w wieku 35-40 lat [3] $]^{9}$ Mimo różnic wiekowych i wynikających z historii choroby, „większość pacjentów, którzy trafiają do środowiska, oni są jakby odizolowani od społeczeństwa. Czyli oni poza nami nie mają kontaktu z ludźmi" [3]. Można z pewnością stwierdzić, że terapeutki traktują pomoc stosunkowo młodszym osobom jako główny sens działania „Środowiska”: wkładają w nią więcej zaangażowania, także emocjonalnego („Ze starszymi to już się trochę inaczej pracuje. (...) To też chodzi o to, żeby ten pacjent tak nie zastygł. Nie został w domu" [2]). A przy tym niezależnie od wieku, liczby wcześniejszych hospitalizacji, czasu, jaki od nich upłynął i różnych perspektyw, które widzą dla nich pracowniczki, osoby pod opieką "Środowiska” są rutynowo określane jako „pacjenci” (rzadziej z odwołaniem do terminologii psychiatrycznej, np. „pacjent schizofreniczny") i w tym rozumieniu używam tej kategorii. Każda z terapeutek miała pod swoją opieką kilkunastu pacjentów.

„Środowisko” „specjalizuje się" przede wszystkim w osobach z chorobami schizoafektywnymi i schizofrenią [1]. O możliwości włączenia do programu pacjenci dowiadują się w szpitalu psychiatrycznym lub w poradni zdrowia psychicznego. Wyrażają zgodę na wizyty domowe terapeuty i nie mogą ich unikać czy odmawiać; wymogiem jest też a namneza (obszerny wywiad z pacjentem) w trakcie pierwszej wizyty terapeutki, dająca wgląd w zarys biografii osoby: wykształcenie, wykonywaną pracę, relacje z rodziną i szerszym otoczeniem społecznym. O kwalifikacji decyduje lekarz psychiatra, lecz chodzi też o trudno definiowalną „zasadność przyjęcia”, rozpoznanie, że w „pacjencie jest potencjał”: dostrzeżenie szansy, że udział w „Środowisku” może mu w czymś pomóc [2]. Pacjent jest przez propozycję „tak jakby mobilizowany, musi podjąć tą decyzję” [3]. Rolę odgrywa tu rodzina: „Powiem tak, głównie to rodzina chodzi i szuka pomocy. I głównie to z ich inicjatywy, rodziny, wypływa. Potem po jakichś takich rozmowach wstępnych, terapeutycznych, z pacjentem, to jakby on też dochodzi do wniosku, że może z tego wiele skorzystać" [2] bądź lekarz: „Ja akurat mam takich pacjentów, że myślę, że to nawet bardziej

\footnotetext{
${ }^{9}$ Liczbami od [1] do [6] oznaczam cytaty z wypowiedzi poszczególnych rozmówczyń.
} 
lekarz miał wpływ większy niż rodzina" [3]. Wszystkie terapeutki są zgodne, że samodzielnie pomocy w „Środowisku” szukają jedynie młode osoby, po pierwszych hospitalizacjach, które mają „dosyć izolacji” i są nią „przestraszone” [2].

„Zasady działania” „Środowiska” obejmują przede wszystkim regularne odwiedziny w domach pacjentów („u nas jest taki standard, że się widzimy raz w tygodniu z tym pacjentem" [3]). Dodatkowo określone przez NFZ wymogi zakładają udział w grupach terapeutycznych: „Fundusz narzuca pewne wymagania, żeby pacjent przynajmniej raz w tygodniu przyszedł do nas na jakieś zajęcia". Ta sama rozmówczyni, psychiatra zespołu, mówi jednak: „Są pacjenci, którzy w ogóle z domu nie wychodzą, więc mamy i takie osoby. Wtedy to tylko na zasadzie wizyt terapeuty" [4]. Z moich badań wynika, że warunek zajęć poza domem nie był ściśle przestrzegany i dopiero dłuższe nieprzyjmowanie domowych wizyt terapeutki wykluczało ze „Środowiska”. Część osób rezygnuje, lecz tylko bardzo nieliczne dlatego, że „poprawiają się [ich] funkcje społeczne" [4], znajdują zajęcie, najczęściej w zakładzie pracy chronionej, lub podejmują edukację. Inna kategoria to osoby starsze, które są przenoszone do Domów Pomocy Społecznej , co automatycznie kończy udział w „Środowisku”.

\section{Chroniczność, wykluczenie i nadzieja sprawczości}

Ciężkie choroby psychiczne jako źródło dyskryminujących wyobrażeń, poczucia zagrożenia i uprzedzeń, ich zakładana nieodwracalność, „nieuleczalność” schizofrenii sprawiają, że badanie sytuacji osób z chronicznymi zaburzeniami lub chorobami psychicznymi staje się $\mathrm{w}$ dużej mierze tożsame $\mathrm{z}$ badaniem mechanizmów stygmatyzacji i sytuacji wykluczenia. Determinujący wpływ ma w równym stopniu chroniczność zakładana, pojawiająca się w młodym wieku wraz z pierwszą hospitalizacją jako przełomowym wydarzeniem, jak i ta wynikająca ze zdrowotnych i społecznych skutków długotrwałej choroby. Sytuację pacjentów „Środowiska” w dużym stopniu definiuje opisywane przez Michela Foucault konstytutywne znaczenie pozytywnej diagnozy psychiatrycznej: rozpoznanie konkretnej choroby psychicznej to w swych konsekwencjach "powierzchowne i drugorzędne działanie w stosunku do prawdziwego pytania stawianego w każdej diagnozie", które sprowadza się do zasadniczego „tak” lub „nie” (Foucault 2006: 266). Pozytywna diagnoza schizofrenii, jako rozstrzygnięcie decydujące o włączeniu danej osoby w mechanizmy instytucjonalnej psychiatrii i jako takie będące formą stygmatyzacji, staje się kluczowa 
dla jej przyszłego społecznego statusu. Uruchamia ona mechanizm wytwarzania chroniczności, odzwierciedlany w opisach sytuacji pacjentów „Środowiska”: od pojawienia się choroby i pierwszej hospitalizacji, odbieranej jako katastrofa i zerwanie w ciągłości biografii, przez postawę niezgody, odrzucenie społeczne, po wykluczenie, wycofanie, stygmatyzację i samonaznaczenie.

Diagnoza choroby psychicznej (w przywoływanych tu przykładach dotyczy to niemal wyłącznie schizofrenii) i następująca hospitalizacja jest nieodmiennie traktowana jako katastrofa życiowa: „pojawienie się choroby to jest taki szok dla pacjenta też. Życie mu się wali, praca, kontakty z innymi ludźmi” [2]. Dotyczy to też bliskich: „To na początku i na rodzinę spada jak grom z jasnego nieba. W momencie kiedy rodzina tak naprawdę nie wie nic o chorobie, to jest to ogromny poziom lęku" [5]. Już w opisach pierwszych reakcji pojawia się antycypowana, także przez same terapeutki, chroniczność: „W ogóle ogromną traumą dla rodziny jest to, że okazuje się, że jest to choroba przewlekła” [1]. Owo „okazuje się" jest tu znakiem determinującego wydarzenia, umiejscawianego w diagnozie psychiatrycznej.

Choroba jest odbierana nie tylko jako nieszczęście, ale jako „ogromne zło” [1] lub kara: „Może trochę ludzie wstydzą się nam terapeutom, lekarzom mówić, że to dopust boży czy jakaś kara, ale kto wie, czy w jakimś momencie nie pojawia się taka myśl” [3]. Towarzyszy temu poczucie wstydu i wycofanie („wtedy to idzie w stronę takiej izolacji" [2]). Opisy pierwszego okresu po diagnozie i hospitalizacji to także pojawienie się rozróżnienia wiekowego w reakcjach otoczenia pacjentów:

Ale przyznam, że nie spotkałam się z tym, żeby jakiś pacjent powiedział tak odważnie, że „jestem schizofrenikiem”. Bo to jest ogromny lęk. To jest wstyd, to jest lęk przed odrzuceniem, przed krytyką, przed oceną, bo jak jesteś chory psychicznie... Na przykład pacjentka ma nawet lęk przed mamą, bo mama mówi, starsza osoba, że „jesteś wariatka". Dotrzeć do takich ludzi, tych starszych, to jest naprawdę praca w kopalni [2].

Na przykład ostatnio miałam taką sytuację, że matka wstydzi się córki, nie chce w ogóle, bo chora, bo tak wygląda, bo co inni powiedzą [6].

Większa otwartość osób młodszych przeciwstawiana jest częstszej nietolerancji starszych, skrywanej za eufemizmami w rodzaju „ze starszymi bywa różnie” [6]. Dlatego młodzi pacjenci odczuwają:

ogromny lęk przed opinią. Że tę chorobę po nich widać, że nie mogą iść do pracy normalnej, że muszą iść do zakładu pracy chronionej. Człowieka młodego się aktywizu- 
je, motywuje i mówi mu, że ta choroba to tak naprawdę nie zamyka mu drzwi do funkcjonowania w życiu [2].

Nawet osoby opisywane jako najbardziej zaangażowane w „Środowisku” odczuwają silny lęk, przez co szpital odbierany jest jako bezpieczny:

Ale od samych tych pacjentów wiem, że oni nieraz się obawiają wychodzić, „no bo co będzie, jak mi sąsiad zada pytanie, co ja robię?". Jakby czasami ten szpital też jest dla nich czymś spokojnym, bo on tam trafia i tam są sami ludzie chorzy i nikt ich nie będzie pytał, co ty robisz. Każdy ma to samo. (...)

Parę osób mam takich, które się obawiają wyjścia w ogóle z domu, bo mogą spotkać sąsiada, który nawet jeśli nie zada pytania, to co sobie pomyśli. „Przecież ja mam dwadzieścia parę lat i ciągle jestem w domu. Że będzie wiedział, że jestem chory" [3].

Wstyd przed otoczeniem i perspektywa bezterminowej opieki nad bliskim powodują, że rodziny przyjmują postawy odrzucenia. Dotyczy to niezgody na samą chorobę („Jest generalnie niezaakceptowanie” [1]), ale też doświadczającej jej osoby:

Jest dużo takiego emocjonalnego porzucenia. (...) mimo że to źle dzieje się od kilkunastu lat i rodzina mogłaby się nauczyć wyłapywać i wesprzeć swojego syna, to rodzina $\mathrm{w}$ tym momencie najchętniej zamyka się w drugim pokoju [1].

Pośrednio także „Środowisko” może stać się adresatem postawy niezgody:

To nieraz ja się spotykałam, że to aż takie było nieprzyjemne dla pacjenta. Bo to było coś takiego, przybiega rodzic i jakby skarży na tego syna: on to i to robi albo tego nie robi. Więc z jednej strony takie, no jakaś otwartość, która ich tam, spust taki, że oni mogą to powiedzieć, i to im pewnie jakoś pomaga. A z drugiej strony takie właśnie oczekiwanie: ja ci wszystko powiedziałem, to ty teraz coś z tym zrób i zmień tą sytuację [3].

Wobec pacjentów postawy rodzin wahają się od chęci pomocy i wsparcia, przez wygórowane oczekiwania, aż po praktyki dyscyplinujące.

Teraz przychodzi mi na myśl taki młody chłopak, który mieszka ze swoją matką i siostrą. On też ma wyższe niepełne (...) i on też miał parę hospitalizacji. I u niego na przykład to jest tak, że kiedy on wraca do takiego wyrównanego nastroju, to może jest taki niepokój w tej rodzinie, ale taka siła, która już go pcha: „dobra, to teraz już jest dobrze, to teraz podejmuj te kolejne [wyzwania], może tu szkołę jakąś, tu pracę trzeba szukać”. (...)

On się spotyka z wieloma takimi wymaganiami i naciskami, tak jakby ta rodzina chciała... No miała tą nadzieję, że to już jest dobrze i to już tak będzie, jakby chciała to 
podtrzymać. A z drugiej strony jest tyle tych wymagań, że nieraz to się znowu sprowadza, z powrotem wraca do punktu wyjścia.

(...) z jednej strony oni sobie zdają sprawę, że ta osoba jest chora, ale ciągle mają takie wymagania jak od zdrowej, że tu o, leży, to leń. Inni pracują, czemu on nie idzie do pracy albo czemu się nie uczy. Tak więc z jednej strony szukanie trochę wsparcia, ale też taka nadzieja na to, że my zrobimy, że on będzie zdrowy, że on będzie no tak się zachowywał cały czas, już to naprawimy [3].

Powtarzający się cykl obejmujący remisje choroby, kolejne nawroty i hospitalizacje powoduje „miotanie się" [2] rodziny:

Czy to jest na zasadzie „O Jezu, znowu” albo „znowu będziemy musieli czekać aż się poprawi, żeby mógł coś tam”. Czy może jakiś brak już nadziei, że nigdy już nie podejmie tych różnych ról, które społeczeństwo wymaga od nas. Jesteś 30-letnim mężczyzną, to powinieneś pracować [3].

Jedna z terapeutek ujęła splot oczekiwań, rezygnacji i obwiniania w formule: „Masz ręce? Masz nogi? To się za mało modlisz" [1].

Problemy dotyczące chroniczności jako źródła trwałej stygmatyzacji i wykluczenia związanego z chorobą psychiczną najdobitniej uwydatniają się w perspektywach założenia rodziny i posiadania dzieci. Sam temat wywołuje lęk w otoczeniu pacjentów, ale i dla terapeutek stanowi trudną barierę: nie przyznają tego otwarcie, lecz w zarysowywanych przez nie szansach reintegracji społecznej pacjentów rodzina i prokreacja wydają się leżeć poza sferą możliwości. Zwykle jednak przyczyny są umiejscawiane w postawie pacjentów („Głęboko tkwi w nim ta bariera, że jak już jestem chory, no to nie mam szans" [2]) lub otoczenia:

Jeżeli mężczyzna chory na schizofrenię, jeżeli nawet szuka gdzieś na portalach randkowych zdrowej kobiety, to tak naprawdę te znajomości wszystkie kończyły się fiaskiem. On się nie przyznawał, a jednak kobieta naciskała, żeby kupić samochód, prawo jazdy, a tu wtedy tak. I wtedy co? I wtedy zawraca i szuka tutaj...[2]

„Tutaj” oznacza ostatnią szansę, to znaczy poszukiwanie partnera czy partnerki wśród osób z chorobami psychicznymi. Jedynie pojedyncze, „wyjątkowo silne” [2] osoby, dzięki wsparciu „Środowiska” stosują pewne formy oporu wobec dyskryminujących ograniczeń. Do wyjątków należy tu przykład pary młodych ludzi:

Pacjentka ma przyjaciela, przyjaciel też chory na schizofrenię, i kiedy oznajmiła, że chce wyjść za mąż rodzinie, spotkała się z wielkim oporem, protestem. Dlatego, że ona 
i on [są chorzy]. Co ona też uczyniła, to poszła gdzieś do księdza biskupa, pytając, bo bardzo jej zależało, i jakby to, co usłyszała, to że nie ma szans na to, żeby mieć rodzinę. Bo z tym się wiąże co - dzieci. A potem rodzina ta, matka z ojcem, wzywając mnie, mówią do mnie wprost: to pani będzie bawiła te dzieci? Jak się coś urodzi? Bo coś takiego się urodzi i oni nie dość, że mają się opiekować i jeździć do córki, to jeszcze mają jej dziecko bawić. Więc jakby przejście przez to teraz graniczy z cudem, żeby tych dwoje ludzi przeszło przez to i sformalizowało związek [2].

Doświadczenie rozmówczyń związane z perspektywami pracy pacjentów także potwierdza sytuację wykluczenia i opisywany w badaniach brak zatrudnienia ${ }^{10}$. Alternatywą jest praca chroniona lub poniżej wykształcenia:

Jest przynajmniej parę takich osób, które mają wykształcenie wyższe, a pracują na dużo niższych stanowiskach. I to, myślę, też jest dla tych osób trudne. Że nie wiem, ktoś ma wyższe wykształcenie, a pracuje w roli osoby sprzątającej. Że podejmuje taką pracę, bo ma trudność ze znalezieniem innej, ale też obawy, że sobie nie poradzi. Że będą takie wymagania, że jednak sobie nie da rady [3].

Wcześniejsza diagnoza schizofrenii i hospitalizacje są zazwyczaj ukrywane: ich ujawnienie powoduje w praktyce odmowę zatrudnienia, jak w przypadku potencjalnej pracodawczyni, która stwierdziła, że „no niestety, przykro jej, ona [osoba aplikująca] sprawia dobre wrażenie, ale ona niestety jej nie zatrudni. Właśnie przez wzgląd na tą diagnozę" [6].

Mimo niedostrzegania szans na zupełne wyjście ze statusu chroniczności pracowniczki „Środowiska” niewątpliwie uznają jego działania za pozytywne i efektywne, lecz odnosi się to niemal wyłącznie do osób młodszych. To one i ich rodziny najchętniej włączają się w jego program („większość młodych ludzi, gdzie jest młody człowiek i rodzina, to przyjmują" [2]). Bliski kontakt pozwala dostrzec wczesne symptomy choroby, zapobiec hospitalizacji i skierować osobę na oddział dzienny: „I tak jest, że ci pacjenci, których mam, to procentowo te pobyty w szpitalach w porównaniu z tym, co było $\mathrm{w}$ przeszłości, no to jest jeden albo dwa pobyty w ciągu kilku lat albo w ogóle. Czyli jest to duża poprawa" [2]. W sytuacji optymalnej rolą „Środowiska” jest też zasadnicza zmiana nastawienia pacjentów i rodzin:

\footnotetext{
${ }^{10} \mathrm{~W}$ momencie postawienia diagnozy schizofrenii pracuje obecnie około połowa pacjentów. Przy pięciu i więcej hospitalizacjach ponad 90\% osób pracujących traci zatrudnienie (Kiejna i in. 2014: $32)$.
} 
Taki rodzaj stygmatyzacji, że po prostu teraz tak, dziecko zachorowało i są takie momenty, że najpierw jest to obwinianie całego świata i Boga, a w momencie kiedy wkracza terapeuta, to już jest wiedza [2].

(...) kontakt i mobilizowanie, takie aktywizowanie tej osoby i wyjście do środowiska, takie szersze spojrzenie na to, że jednak z tą osobą też można coś zrobić, można jej pomóc. Że to nie jest na zasadzie: a, schizofrenia, to już dobra, to tam szpital, leki może brać, jak będzie brał to będzie stabilny, nie będzie brał to koniec. Że to właśnie też podejście takie, otwarcie się też na jakąś terapię, nie tylko że do szpitala i koniec [3].

Co się niekiedy udaje, nie tylko w przypadku osób młodszych:

Ale też mam rodzinę, dzieciak równie chory, w podobnym wieku, bardzo ciężki przebieg, ale rodzice, gdzie wiem, że to też był dla nich szok ogromny, ale powoli, powoli, oni wreszcie zaakceptowali, że ta choroba jest i oni mu cały czas mówią: „to jest tylko część ciebie". I dzieciak zupełnie inaczej funkcjonuje, dzieciak skończył szkołę policealną i pracuje [1].

Teraz mam pacjentkę, ona akurat nie schizofrenia, ale zaburzenia schizoafektywne. I ona też wielokrotne miała hospitalizacje, jedna po drugiej, nie wiem, z osiem czy coś koło tego, teraz już od dwóch lat jest stabilnie, ona myśli o pójściu do pracy, teraz pomaga w opiece nad wnuczkami swojemu synowi, więc to jakby dla niej jest praca [3].

Mimo uznania możliwości zmniejszenia stygmatyzacji za bardzo ograniczone, a założenia chroniczności za niepodważalne, w perspektywie terapeutek „Środowisko” jest wartością, nawet jeśli stanowi dla pacjenta i rodziny jedyną „zdrową” alternatywę wobec wykluczenia:

Tracą pracę albo nie zdążyli jej podjąć, bo dużo osób zaczęło chorować w wieku szkolnym, z powodów takich też ich lęków, niepokojów, że oni nie wychodzą sami, że się obawiają. Przez psychopatologię ich taką czystą. Obawiają się wyjścia do ludzi i to [„Środowisko”] jest jakby wielokrotnie jedyny ich kontakt z drugim człowiekiem, poza tą rodziną, którą tam widzą na co dzień. I ta rodzina nie zawsze funkcjonuje zdrowo. Więc to też jest jakoś odciążające, więc tu wchodzi osoba, która im pomaga funkcjonować. (...)

To jest dla nich... zdrowy taki element wchodzi do ich życia, i który jakoś ich uczy też funkcjonowania, i w tej rodzinie swojej, która nierzadko nie funkcjonuje zdrowo, i pomaga im się jakoś odnaleźć, radzić sobie z różnymi zachowaniami różnych członków, ale też i uczenie jak się zachowywać w tym społeczeństwie, które ma być zdrowe [5].

Człowieka młodego się aktywizuje, motywuje i mówi mu, że ta choroba to tak naprawdę nie zamyka mu drzwi do funkcjonowania w życiu. To ten człowiek ma większe, jak się tutaj konsoliduje, integruje z innymi, to ta siła jego wzrasta, on nie jest 
zamknięty sam w swoim mieszkaniu. Tę siłę łączy z innymi ludźmi i widzi, że inni idą do pracy, inni podejmują wyzwania, więc on idąc za tym idzie i zaczyna sobie inaczej radzić z chorobą [6].

„Środowisko” jako takie jest symbolem nowych praktyk w psychiatrii:

dojeżdżałam do Hajnówki, i była przemiła pani doktor. I ona do mnie mówiła tak: pani M., co pani z nim rozmawia, przecież to schizofrenik. I ona to mówiła z całej życzliwości: no po co sobie głowę zawracać, przecież to się nic nie zmieni. (...)

W starych podręcznikach psychiatrii, jeszcze lata temu, to o rodzinie czy o bliskich to tam nie było słowem. Bo schizofrenia, bo wszystkie zaburzenia psychotyczne, to naprawdę rodzina nie miała znaczenia [1].

Ale też dostrzega zmiany w otoczeniu społecznym:

Bardziej mam w głowie, jak są u nas pacjenci, którzy chorują na przykład 30 lat, i ich wspomnienia, gdzie na przykład leżeli w szpitalu, i to jak ciężko byli traktowani przez ludzi, ale tak krańcowo. Teraz owszem i ja widzę ten taki lęk przed schizofrenią, oparty na małej wiedzy. Ale to już nie jest ta komórka ${ }^{11} \ldots[1]$.

Antycypowana chroniczność zasadniczo definiuje perspektywę samych pracowniczek „Środowiska”: „Na przykład taki młody człowiek, trzydziestoletni, choruje od pierwszego roku studiów, był pierwszy rzut, i naprawdę, jest źle i nigdy prawdopodobnie nie będzie naprawdę stabilnie" [1]. To samo dotyczy innego 30-letniego pacjenta, „który nie skończy studiów i raczej nie założy rodziny” [3]. Sformułowania "prawdopodobnie” i „raczej” rozumiem jako eufemizmy, osłabiające internalizację nieuchronności wykluczających skutków choroby i praktyk dyskryminujących. Rzadziej pojawia się to w otwartym rozpoznaniu:

Ja to czasami dalej się spotykam z taką opinią, jak to mówi się o pacjencie, który tam nie wiem, przez jakiś dłuższy czas nic się u niego nie zmienia, (...) najprościej mówiąc: źle funkcjonuje, nie tak jak byśmy chcieli. I ktoś podsumowuje to: a, bo my tu już z nim nic nie zrobimy [3].

To sytuacja, gdy założenie chroniczności jest bliskie zakwestionowaniu sensu pomocy, odnosi się jednak jednoznacznie do przeszłości; jej opis jest zarazem świadomie przeciwstawiany etosowi pracy terapeutek. Pracowniczki „Środowiska” są

\footnotetext{
${ }^{11}$ Rozmówczyni odwołuje się do obecnych w dyskursie publicznym informacji o rodzinach przetrzymujących osoby uznane za chore psychicznie w zamkniętych pomieszczeniach.
} 
zgodne, że „zanikają już te średniowieczne wzorce takiego piętnowania. Rodzą się te zdrowe wzorce" [2], a zarazem przyznają, że na otwarte ujawnienie własnej choroby i hospitalizacji jest jeszcze za wcześnie: „To jeszcze nie jest ten czas. (...) To jest kwestia przyszłości" [2].

\section{Podsumowanie}

Praktyka „Środowiska” jest organizowana przez założenie chroniczności psychiatrycznej, co oznacza, że powiązanie medycznych konsekwencji chorób i wykluczenia społecznego determinuje działania pracownic w perspektywie obecnego i przyszłego życia pacjentów. W moich badaniach dominował sposób definiowania kluczowych, uznawanych za niezmienne uwarunkowań codziennej praktyki jako pochodnych chroniczności, której atrybutem jest bezterminowe „bycie na lekach” i akceptacja trwałego powiązania pacjentów, rodzin i instytucji psychiatrii. Konkretna diagnoza, istotna w terapii farmakologicznej, staje się drugorzędna wobec chroniczności nie tylko w odniesieniu do społecznej sytuacji pacjentów, lecz i działań ZLŚ.

Terapeutki nie tylko uznają status „pacjenta” za trwały: włączają w swoją perspektywę doznawanie przez osoby hospitalizowane i ich otoczenie gwałtownego, definiowanego jako katastrofa, zerwania w ciągłości biografii. Historie pacjentów są przez to przede wszystkim narracjami o stracie, nawet jeśli nie oznacza to przyjęcia radykalnej interpretacji, mówiącej, że w przypadku osoby ze schizofrenią nie istnieje społeczne „po”, a jedynie „przed” (Barham, Hayward 2002: 2). Towarzyszy temu doświadczanie utraty wartości, deprecjacji i samonaznaczenie: ogromna większość pacjentów reaguje wycofaniem i odizolowaniem, wzmacnianym przez odrzucenie lub wstyd rodziny (Leff, Warner 2006: 87). Przedefiniowaniu podlega każdy aspekt życia, „od umiejętności znalezienia i utrzymania pracy, po zdolność budowania i podtrzymywania relacji" (Cohen 2008: ix). Splot uwarunkowań medycznych i społecznych, tworzących chroniczność powoduje, że problemem jest nie tylko stygmatyzacja bądź wykluczenie. Próby pomocy, „aktywizacji” mogą być odbierane jako formułowanie nierealistycznych oczekiwań, rodzaj presji i przymusu, przekształcając się w praktyki dyscyplinujące (Mol 2008: 4). Stąd uznanie pozytywnej roli szpitala psychiatrycznego, zapewniającego pacjentom szczególne, nie powodujące presji otoczenie, nawet jeśli oznacza to pobyt w instytucji zamkniętej. Powtarzające się hospitalizacje (przez założenie chroniczności także te antycypowane), remisje, próby powrotu do poprzedniego 
życia, postawy nadziei i rezygnacji, są zarówno dla pacjentów, jak i rodzin niezwykle wymagającym, często destruktywnym doświadczeniem ${ }^{12}$, toteż działania terapeutek nakierowane są na pomoc w warunkach podzielanej chroniczności.

Połączenie nieodwracalności skutków choroby, poczucia doznanego nieszczęścia i katastrofy, bezterminowość statusu pacjenta, uznanie radykalnie ograniczonych możliwości - uwarunkowania te, tworząc kontekst działania terapeutek, konstytuują opartą na złożeniu chroniczności perspektywę daremności, która określa ramy działania „Środowiska”. Zasygnalizowane wyżej nawiązania do ogólnych wniosków z badań w odmiennych realiach mają na celu pokazanie uogólnionego wymiaru daremności jako konsekwencji terapeutycznych ograniczeń psychiatrii. W lokalnym kontekście daremność odnosi się do relacji między brakiem skutecznej terapii i definiowaniem przez terapeutki roli „Środowiska” wobec mechanizmów wykluczenia i szans reintegracji społecznej.

Rozpoznanie daremności sprawia, że jednym z głównych celów w pracy ZLŚ są rzadsze i krótsze hospitalizacje pacjentów. Oparte na stałym przyjmowaniu środków farmakologicznych utrzymywanie pacjenta w „stabilnym” stanie, nawet bez radykalnej poprawy, staje się kluczowe w sytuacji, gdy każdy nawrót, każdy epizod pogorszenia, ma charakter coraz bardziej niszczący. Zapobieganie nawrotom i hospitalizacji stanowi niekwestionowaną, pozytywną wartość i, obok wpływania na otoczenie pacjentów, właściwy sens pracy terapeutek. Skupienie na podtrzymywaniu stabilności, unikanie czy łagodzenie kryzysów (zdrowotnych i w relacjach z rodzinami) związanych z nawrotem choroby oznacza zarazem bezterminową opiekę i podzielaną chroniczność. Z jednej strony, udział w „Środowisku” nie ma założonych ram czasowych, o ile pacjent nie odmawia wizyt domowych. Z drugiej natomiast, relacje społeczne większości pacjentów ograniczają się do rodziny, a terapeutki stanowią ich jedyny „kontakt z ludźmi”13.

Praktyka „Środowiska” oznacza też kontekstualne rozpoznawanie możliwości i definiowanie reguł działania. Rzecz nie tyle w jej dystansie do uniwersalizującego dyskursu psychiatrii środowiskowej (np.: „Z założenia psychiatria środowiskowa zapewnia opiekę całej ograniczonej geograficznie populacji bez różnicy wieku, płci,

\footnotetext{
${ }^{12}$ Spośród „młodych chroników” „Wielu wchodzi ze swoimi rodzinami w powtarzający się cykl nadziei, strachu, wściekłości, wstydu, właściwie w przemocowy konflikt więźniów zamkniętych w pokoju bez wyjścia" (Pepper i in. 2001: 7).

${ }^{13}$ Jak pisał Erving Goffman, specyfika opieki psychiatrycznej sprawia, że pracownicy niższego szczebla, działający „w dziedzinie społecznego kontaktu”, dokonują często istotniejszych działań niż lekarze psychiatrzy, którzy formalnie podejmują decyzje dotyczące pacjentów (Goffman 2011: 333).
} 
różnic klasowych, kulturowych" [Pietrzykowska 2011:606]), co w nakładaniu się tak zlokalizowanych uwarunkowań i daremności. Terapeutki umiejscawiają swoją pracę zarówno w kontekście chroniczności, jak i roli „Środowiska” w ramach systemu opieki psychiatrycznej. Dwa ZLŚ(jedyne w Białymstoku i na terenie powiatu) obejmowały w sumie ok. 30 pacjentów ${ }^{14} \mathrm{i}$, jak wynika z moich rozmów z pracownicami obu zespołów, praktycznie wszyscy byli mieszkańcami miasta ${ }^{15}$. Działanie ZLŚ było traktowane jako niezwykle pozytywne („wiedza” terapeutek „Środowiska” przeciwstawiana stygmatyzującym postawom rodzin i otoczenia), lecz będące marginalną, od wielu lat nierozwijaną częścią systemu (Rogowski 2000).

Sednem kontekstualnego definiowania sytuacji - stanu pacjentów, relacji w rodzinach, szans uniknięcia wykluczenia - jest otwarte opisywanie rozmytej bądź pomijanej podmiotowości pacjentów w kwestii decyzji o włączeniu do „Środowiska”. W praktyce decyzja jest najczęściej negocjowana między rodziną i odgrywającym sprawczą rolę lekarzem. Kluczowym kryterium jest "potencjał” dostrzegany w pacjencie, przesądzający o jego udziale w programie. Biorąc pod uwagę większe zaangażowanie w pomoc młodym pacjentom, ogólną charakterystykę starszych osób w ich otoczeniu jako uosabiających trwałość społecznych postaw stygmatyzujących i wykluczających, opisy trudnej pracy ze starszymi pacjentami - nieformalnym, lecz decydującym wyznacznikiem staje się młody wiek. Logikę praktyki „Środowiska” jako skupionego na zapobieganiu wykluczeniu młodych osób łamią jednak dwa jej inne, ważne aspekty. Nieprzestrzeganie wymogu uczestnictwa w zajęciach terapeutycznych poza domem przesuwa ją wyraźnie w sferę opieki i „chronicznej pracy domowej”. Drugim problemem jest perspektywa założenia rodziny i posiadania dzieci przez młode osoby ze schizofrenią. Terapeutki opisywały liczne sytuacje, które obrazują silny społeczny lęk przed seksualnością osób z chorobami psychicznymi. Gdybym jednak miał opierając się na moich badaniach formułować wnioski na temat ich własnych zapatrywań, mówiłyby one o podzielanym i zinternalizowanym (choć nieartykułowanym otwarcie) uznaniu choroby psychicznej za przeciwwskazanie prokreacji.

Kwestia podmiotowości umieszcza „Środowisko” w kontekście analiz opresyjnych praktyk psychiatrii. Krytyka etyczna zakłada, że żadna forma opieki lub pomocy,

\footnotetext{
${ }^{14}$ Psychiatryczna opieka zdrowotna $w$ województwie podlaskim, Podlaski Urząd Wojewódzki, 2011. https://www.google.pl/search?q=psychiatria+\%C5\%9Brodowiskowa+podlaskie\&oq=psychiatria$+\%$ C5\%9Brodowiskowa + podlaskie\&aqs $=$ chrome. .69i57.1926j0j7 \& sourceid=chrome\&ie=UTF-8. Dostęp: 17.04.2017.

${ }^{15} \mathrm{~W}$ okresie międzywojennym te dysproporcje oznaczały niemal całkowity brak jakiejkolwiek opieki psychiatrycznej dla wiejskich mieszkańców Podlasia (Bartoszewski 1962: 730).
} 
jeśli jest związana z przymusem, uprzedmiotowieniem lub zawiera „karę” za niedotrzymywanie jej warunków, nie ma wartości terapeutycznej(Brodwin 2013: 181). W opisywanej praktyce takimi uwarunkowaniami są zgoda na anamnezę i wizyty domowe terapeutek ZLŚ, wymóg przyjmowania lekarstw, ale też same procedury włączania do programu. Nie oznacza to przyjmowania przeze mnie perspektywy radykalnego upodmiotowienia, gdzie psychiatria środowiskowa jest definiowana jako „program oparty na przymusie” (Spindel, Nugent 2000: 96), uzależniający uczestników, zakładający ich niekompetencję i odtwarzający reguły charakterystyczne dla zamkniętych szpitali psychiatrycznych ${ }^{16}$. Opisywane tutaj, podtrzymywane w praktyce „Środowiska”, trwałe powiązanie pacjentów z instytucjonalną psychiatrią, pozwala jednak wpisać ten model psychiatrii środowiskowej w procesy transinstytucjonalizacji (Primeau i in. 2013: 2, Załuska 2006: 284), oznaczające jedynie przesunięcie przyporządkowania pacjentów w obrębie instytucjonalnej opieki.

\section{Bibliografia}

Bachrach, L.L. (1988). Defining Chronic Mental Illness: A Concept Paper. Hospital and Community Psychiatry, 39 (4), 383-388. DOI: 10.1176/ps.39.4.383.

Barham, P. (1993). Schizophrenia and Human Value: Chronic Schizophrenia, Science and Society. London: Free Association Books.

Barham, P. (1997). Closing The Asylum: The Mental Patient in Modern Society. London: Penguin Books.

Barham, P., Hayward, R. (2002). From the Mental Patient to the Person. London: Routledge.

Bartoszewski, I. (1962). Historia Szpitala w Choroszczy. Neurologia, Neurochirurgia i Psychiatria Polska, XII (5), 729-735.

Borowski, T. (1972). Opieka rodzinna nad przewlekle chorymi psychicznie. Biuletyn Informacyjny Instytutu Psychoneurologicznego, 3 (9), 61-76.

Bracken, P., Thomas, P. (2001). Postpsychiatry: a New Direction for Mental Health. British Medical Journal 322 (7288), 724-727. DOI: https://doi.org/10.1136/bmj.322.7288.724

\footnotetext{
${ }^{16}$ Odpowiedzią na ten rodzaj krytyki jest zarzut odwoływania się do klasycznych założeń liberalizmu, mówiącego o jednostce obdarzonej wolnością do samostanowienia (psychiatria ma odmawiać jej prawa wyboru i wzmacniać zależność, uznawaną za nieuprawnioną z zasady), co oznacza nie tylko pomieszanie wartości politycznych i terapeutycznych (Brodwin 2013: 182), ale też zanegowanie realności chorób psychicznych i cierpienia osób doświadczających ich konsekwencji.
} 
Brodniak, W. A. (2000a) Choroba psychiczna w świadomości społecznej. Warszawa: Oficyna Naukowa.

Brodniak, W. A. (2000b) Przegląd badań nad postawami społeczeństwa wobec chorób psychicznych, osób psychicznie chorych i instytucji psychiatrycznych w Polsce (19631999). Postępy Psychiatrii i Neurologii 9 (3), 339-351.

Brodwin, P. (2008) The Coproduction of Moral Discourse in U.S. Community Psychiatry. Medical Anthropology Quarterly 22 (2), 127-147. DOI: 10.1111/j.1548-1387.2008.00011.x.

Brodwin, P. (2011). Futility in the Practice of Community Psychiatry. Medical Anthropology Quarterly 25 (2), 189-208. DOI: 10.1111/j.1548-1387.2011.01149.x.

Brodwin, P. (2013). Everyday Ethics: Voices from the Front Line of Community Psychiatry. Berkeley: University of California Press.

Bronowski, P., Sawicka, M., Charzyńska, K. (2011). Home Care Services in the Community Treatment of Mentally Ill Persons. Archives of Psychiatry and Psychotherapy, 3, 31-40.

Bronowski, P., Sawicka, M., Kluczyńska, S. (2009), Funkcjonowanie społeczne osób przewlekle chorych psychicznie uczestniczących $w$ środowiskowych programach wsparcia społecznego. Postępy Psychiatrii i Neurologii, 18 (1), 43-50.

Bronowski, P., Załuska, M. (2008). Social Support of Chronically Mentally Ill Patients. Archives of Psychiatry and Psychotherapy, 10 (2), 13-19.

Burns, T. (2004). Community Mental Health Teams: A Guide to Current Practices. New York: Oxford University Press.

Cohen, R.M. (2008). Strong at the Broken Places: Voices of Illness, a Chorus of Hope. New York: HarperCollins.

Drake, R.E., Green, A.I., Mueser, K.T., Goldman, H.H. (2003). The History of Community Mental Health Treatment and Rehabilitation for Persons With Severe Mental Illness. Community Mental Health Journal, 39 (5), 427-440. DOI: 10.1023/A:1025860919277.

Estroff, S.E. (1985). Making It Crazy: An Ethnography of Psychiatric Clients in An American Community. Berkeley \& Los Angeles: University of California Press.

Falicki Z., Stankiewicz M. (1997). Opieka rodzinna w gminie Choroszcz. W: G. Zalewski (red.), Kontrowersje w psychologii i filozofii medycyny. Skrypt dla studentów medycyny i farmacji, ss. 136-142. Białystok: Wydawnictwo Uczelniane.

Foucault, M. (2006). Psychiatric Power. Lectures at the College de France 1973-74 (przeł. G. Burchell). Chippenham: Antony Rowe Ltd. 
Goffman, E. (2011). Instytucje totalne. O pacjentach szpitali psychiatrycznych i mieszkańcach innych instytucji totalnych (przeł. O. Waśkiewicz, J. Łaszcz). Gdańsk: Gdańskie Wydawnictwo Psychologiczne.

Graeber, D. (2012). Dead Zones of the Imagination. On Violence, Bureaucracy, and Interpretive Labor. HAU: Journal of Ethnographic Theory, 2 (2), 105-128. Doi.org/10.14318/hau2.2.007

Kajzer, J. (1967). Spostrzeżenia na temat resocjalizacji psychicznie chorych w ramach opieki domowej. Psychiatria Polska, 1(3), 313-319.

Kiejna, A., Piotrowski, P., Adamowski, T. (red.).(2014). Raport „Schizofrenia. Perspektywa społeczna. Sytuacja w Polsce". Warszawa: Polskie Towarzystwo Psychiatryczne.

Kleinman, A.M. (1988). Rethinking Psychiatry: from Cultural Category to Personal Experience. New York: The Free Press.

Lamb, H.R. (2001). Deinstitutionalization at the Beginning of the New Millennium. New Directions for Mental Health Services, 90, 3-20. DOI: 10.1002/yd.23320019003.

Leff, J., Warner, R. (2006). Social Inclusion of People with Mental Illness. Cambridge: Cambridge University Press.

Link, B.G., Phelan, J.C. (2010). Labeling and Stigma. W: T.L. Scheid, T.N. Brown (eds.), A Handbook for the Study of Mental Health. Social Contexts, Theories, and Systems, ss. 571-587. New York: Cambridge University Press.

Mattingly, Ch. (2010). The Paradox of Hope. Journeys Through a Clinical Borderland, Berkeley: University of California Press.

Mattingly, Ch. (2014). Moral Laboratories: Family Peril and the Struggle for a Good Life, Berkeley: University of California Press.

Mechanic, D., Rochefort, D.A. (1990). Deinstitutionalization: An Appraisal of Reform. Annual Review of Sociology 16, 301-327. Doi.org/10.1146/annurev.so.16.080190.001505

Mol, A. (2008). The Logic of Care: Health and the Problem of Patient Choice. New York: Routledge.

Parry-Jones, W.L. (1981). The Model of the Geel Lunatic Colony and Its Influence on the NineteenthCentury Asylum System in Britain. W: A. Scull (ed.), Madhouses, Mad-doctors, and Madmen. The Social History of Psychiatry in the Victorian Era, ss. 201-217. Philadelphia: University of Pennsylvania Press.

Paulson, G. (2012). Closing the Asylums: Causes and Consequences of the Deinstitutionalization Movement. Jefferson: McFarland.

Pepper, B., Ryglewicz, H., Kirshner. M.C. (2001). The Uninstitutionalized Generation: A New Breed of Psychiatric Patient. New Directions for Mental Health Services, 14, 3-14. 
Peter, S. von (2010). The Temporality of „Chronic” Mental Illness. Culture, Medicine and Psychiatry 34 (1), 13-28. Doi: 10.1007/s11013-009-9159-x.

Pietrzykowska, B. (2011). Psychiatria środowiskowa i organizacja psychiatrycznej opieki zdrowotnej. W: A. Bilikiewicz (red.). Psychiatria. Podręcznik dla studentów medycyny, ss. 605-617. Warszawa: Wydawnictwo Lekarskie PZWL.

Primeau, A., Bowers, T.G., Harrison, M.A., XuXu (2013). Deinstitutionalization of the Mentally Ill: Evidence for Transinstitutionalization from Psychiatric Hospitals to Penal Institutions. Comprehensive Psychology, 2 (2), 1-10. Doi.org/10.2466/16.02.13.CP.2.2.

Rhodes, L.A. (1991). Emptying Beds: The Work of an Emergency Psychiatric Unit. Berkeley and Los Angeles: University of California Press.

Rogowski, S.(2000). Psychiatria środowiskowa w Białymstoku - od teorii do praktyki. Postępy Psychiatrii i Neurologii 9 (3), 389-401.

Różycki, A. (1971). Środowisko instytucji szpitalnej i jej wpływ na powstanie „psychozy egzogennej”zwanej chorobą szpitalną. W: Pamiętnik Drugich Gdańskich Dni Lecznictwa Psychiatrycznego, ss. 361-366. Gdańsk: Polskie Towarzystwo Psychiatryczne.

Scheper-Hughes, N. (1982). Anthropologists and the „Crazies”: Recent Works in Cultural Psychiatry. Medical Anthropology Newsletter, 13 (3), 1-2, 6-11.

Scull, A. (1989). Social Order/Mental Disorder. Anglo-American Psychiatry in Historical Perspective. Berkeley: University of California Press.

Terajewicz, W.(1935). Opieka pozazakładowa w Choroszczy. Nowiny Psychjatryczne XII (III-IV), 211-219.

Van Dongen, E. (1998). "I wish a happy end". Hope in the Lives of Chronic Schizophrenic Patients. Anthropology \& Medicine, 5 (2), 169-192. DOI https://doi.org/10.1080/13648470.1998.996 4556.

Velpry, L. (2008). The Patients View: Issues of Theory and Practice. Culture, Medicine and Psychiatry 32 (2), 238-258. Doi: 10.1007/s11013-008-9086-2.

Wciórka, J. (2000). Psychiatria środowiskowa: idea, system, metoda i tło. Postępy Psychiatrii i Neurologii 9 (3), 319-337.

Załuska, M. (2006). Środowiskowy model leczenia psychiatrycznego a zmiany w strukturze lecznictwa w ostatnich latach w Polsce. Postępy Psychiatrii i Neurologii, 15 (4), 277-285.

Załuska, M., Protm K., Bronowski, P. (2007). Psychiatria środowiskowa jako środowiskowa opieka nad zdrowiem psychicznym. Warszawa: Instytut Psychiatrii i Neurologii. 
